\title{
Chapter 9 \\ How Nations Resurge: Overcoming Historical Inequality in South Africa
}

\author{
Yoichi Mine
}

South Africa is known for its light and shadow: Nelson Mandela's moral leadership in constructing a "rainbow nation" on the one hand, and horrifying inequality as a legacy of apartheid on the other. The slogan of Mandela's African National Congress (ANC) for the first non-racial general elections in 1994 was "Better Life for All." At the time, ordinary voters expected that racial and social disparity would gradually ameliorate even though the economy could be lackluster. After the graceful retirement of Mandela, however, social and economic inequality persisted. The hideous contrast between luxury houses with swimming pools in affluent suburbs and sprawling shacks in impoverished townships remains, and has intensified in the post-apartheid era. ${ }^{1}$ The ranks of rich white households are gradually joined by black African elites, thereby creating prominent intra-racial inequality within the black African population in addition to lingering black-white inequality.

Statistically, the level of South Africa's inequality is the worst in the world. According to the World Bank, South Africa's GINI coefficient of 0.634 (2011) is the highest worldwide, much higher than those of other unequal countries such as Zambia's 0.571 (2015), Brazil's 0.513 (2015), Colombia's 0.511 (2015), Panama's 0.510 (2015), and Rwanda's 0.502 (2013). ${ }^{2}$ One consequence is a high crime rate in urban spaces. Homicide is rampant in cities like Cape Town and Johannesburg, characterized by inhumane ferocity matched only in several violent Latin American cities. The economist Branko Milanovic classifies world inequality into three

\footnotetext{
${ }^{1}$ These spaces are often adjoined, separated by blindfold walls, roads, and rivers. Graphic aerial pictures captured by a drone are presented here: Unequal Scenes, http://unequalscenes.com. Accessed October 15, 2017.

${ }^{2}$ World Bank data, https://data.worldbank.org/indicator/SI.POV.GINI, Accessed October 15, 2017. There are different methods to calculate GINI, and South African economists estimate that the country's GINI has been hovering as high as 0.7. See Fig. 9.5.
}

Y. Mine ( $\varangle)$

Graduate School of Global Studies, Doshisha University, Kyoto, Japan

e-mail: ymine@mail.doshisha.ac.jp

K. Tsunekawa and Y. Todo (eds.), Emerging States at Crossroads,

Emerging-Economy State and International Policy Studies,

https://doi.org/10.1007/978-981-13-2859-6_9 
categories. The first is inequality between citizens within a nation, the second is international inequality between national averages, and the third is global inequality between citizens across nations. In the last category, all individuals are treated as citizens of the global community regardless of nationality. If the world is considered a single virtual nation-state, the global inequality measured by the GINI coefficient is estimated to be around 0.7 (Milanovic 2011, Chap. 3). Thus, we may justifiably regard South Africa as a microcosm of the world, given that the level of inequality within this country is the closest to the reality of global inequality.

South Africa's post-apartheid economy is not only unequal but also stagnant. Defining the middle-income trap, Kharas and Kohli (2011) highlighted Brazil and South Africa as typical cases of "trapped" countries, and proposed alternative growth strategies for their policymakers. In order to secure stable growth paths for emerging states, upgrading technological capacity and elaborating redistributive measures are of prime importance. To this end, effective coordination of conflicting interests is necessary (Chap. 1 of this volume).

Policy coordination involving vocal stakeholders might be possible in South Africa in the short term, not least because of the legacy of post-apartheid coalition making. In the longer term, however, excessive inequality combined with structural unemployment remains a major constraint on coherent policy making for efforts to catch up. Inequality tends to make "politics more discordant and fractious, thus discouraging the centripetal and consensual politics" (Doner and Schneider 2016, p. 620). In today's South Africa, a substantial part of the population is excluded from the productive sector, and this situation cannot be effectively redressed only with conventional redistributive measures. This chapter contends that, in order for South Africa to pull out of the "trap," it is critical not only to make the working population more productive and innovative, but also to create decent jobs for the chronically unemployed in both cities and the countryside, thereby reinforcing national cohesion. While part of South Africa is considered a "knowledge economy," the country also bears aspects of the least developed countries (LDCs) in Africa. For South Africa as a special type of emerging state in Africa, therefore, a strategic combination of policies for middle-income and low-income countries is desirable. And, strong commitment to a set of agreed policies is required.

Following this introduction, Sect. 9.1 of the chapter characterizes the basic structure of the South African economy and identifies its position in Africa and in the world of emerging economies. Section 9.2 traces the historical origin of inequality and argues that the land and labor policies of the colonial/apartheid regime laid the foundation of the structural unemployment that persists today. Section 9.3 portrays South Africa's party politics after apartheid and describes how major political forces attempt to gain a following among the "black middle class." Section 9.4 reviews a series of development policies of the ANC government, indicating that the lack of resoluteness hinders implementation of policies that would make the South African economy more inclusive and dynamic. In conclusion, Sect. 9.5 argues that short-term policies to upgrade technological capacity should be combined with tenacious policy efforts that give voice to the poor and address the root causes of inequality. 


\subsection{South Africa as an African Middle-Income State}

South Africa occupies $4 \%$ of the surface land of sub-Saharan Africa, and accounts for $6 \%$ of the total population of the region in 2015. Its share in the total GDP of sub-Saharan African countries was 19\% in 2016, second to Nigeria (28\%).

However, the presence of South Africa in the region is much larger than the size of its GDP. South Africa is the base of the most robust manufacturing industry in Africa, and its enterprises and investors are conspicuous in the fields such as formal banking, infrastructure development, retail chains, tourism and even private military services. The exceptional position of South Africa becomes evident when comparing GDP per capita; setting aside small, high-growth countries such as the Seychelles, Mauritius and Botswana, South Africa is the only major African country that reached the level of $\$ 4,000$ as early as 1970 , even though its economic power was totally controlled by the white minority at the time (Fig. 9.1). ${ }^{3}$ The huge gap in average income between South Africa and the rest of the continent is the major reason why South Africa has attracted a multitude of migrants from across the continent since the abolishment of apartheid in 1994.

Economically, South Africa was clearly an "emerging" state until the early 1970s. The manufacturing industry expanded rapidly in the boom period occasioned by the Second World War. By 1948 when the National Party (NP) — supported by Afrikaners, the descendants mainly of continental European settlers in the 17th century-seized power to consolidate the apartheid regime, the manufacturing sector was already larger than agriculture and mining. The share of manufacturing and construction in GDP reached 27\% in 1970. The industrialization of South Africa was realized by the combination of cheap labor of indigenous black African workers and the import-substituting industrialization policy which was not only the default option for developing nations in the post-war period but also preferred by the Afrikaner nationalists who controlled state power against the hegemonic British Empire. The apartheid regime was, however, unsustainable; the black African consumer market was dwarfed, the labor market suffered the shortage of skilled workforce, and international isolation seriously hampered South Africa's access to the global financial market and innovation. As such, the prolonged recession in the 1980s was structural rather than temporal (Lipton 1985; Feinstein 2005).

Although the establishment of the democratic regime in 1994 was expected to strengthen South Africa's industrial base, the country actually witnessed rapid deindustrialization. The share of manufacturing in GDP contracted from 20\% in 1995 to $12 \%$ in 2015 , while that of finance, real estate and business services increased from 14 to $18 \%$ in the same two decades. South Africa is the only African country that accommodates the substantial automobile industry as part of global value chains, though the industry is exposed to harsh competition from Asian rivals (Barnes 2014). In 2015, South Africa's total trade accounted for 63\% of GDP. The export of machinery, electronics and transportation accounted for $23 \%$ of total export, and the import

\footnotetext{
${ }^{3}$ The sum of the GDP of the seven countries listed in Fig. 9.1 accounted for $68 \%$ of the total GDP of sub-Saharan Africa in 2016.
} 
6,000 1990 GK \$
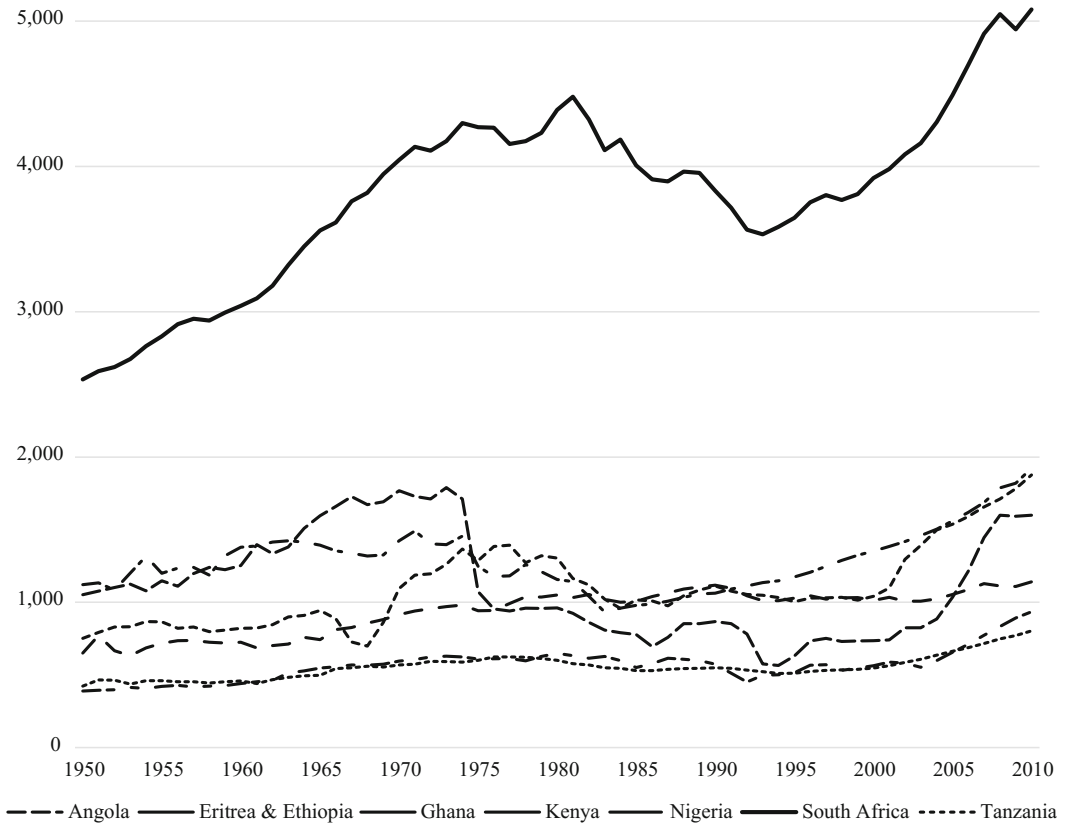

Fig. 9.1 GDP per capita change in major sub-Saharan African countries, 1950-2010. Source Based on the Maddison-Project. https://www.rug.nl/ggdc/historicaldevelopment/maddison/ releases/maddison-project-database-2013. Accessed 15 October 2017

of the same category of goods constituted $34 \%$ of total import, while the share of the export of minerals, metals, stone and glass was $38 \%$. South Africa's deficit in the trade of manufacturing goods is therefore amply compensated for by the export of natural resources. In the case of Africa's largest economy, Nigeria, the trade/GDP ratio was $22 \%$ in 2015 , while $76 \%$ of export was classified as raw materials, mostly crude oil. Compared to this, the South African economy is more deeply embedded in the global trade regime, and its mineral rent plays only an auxiliary role. ${ }^{4}$

Despite the demise of apartheid, the lifting of sanctions and the full inclusion of South Africa into the global economy, the country's growth performance fell short of expectations. Figure 9.2 compares the changes of GDP per capita in South Africa, Brazil, South Korea, Indonesia and Nigeria, as well as Malaysia whose Bumiputera policy was examined by South African policymakers to craft the post-apartheid

\footnotetext{
${ }^{4}$ These figures are taken from the database of Statistics South Africa (http://www.statssa. gov.za/?page_id=1854\&PPN=P0441\&SCH=6983) and the World Integrated Trade Solution ( https://wits.worldbank.org/CountryProfile/en/ZAF and https://wits.worldbank.org/CountryProfile/ en/NGA). Accessed October 15, 2017.
} 
affirmative action policy. Although the upward turn of South Africa's GDP per capita after the abolishment of apartheid in 1994 is visible, the pace of advancement is frustratingly slow. South African economy still remains "trapped."

Nations generate rapid economic growth when they transform their labor force from a low-productivity to a high-productivity stage, and continuously upgrade their skills and innovativeness. However, the South African labor market excludes more than one third of human resources from the productive sector. Figure 9.3 shows the extreme level of unemployment in South Africa. The official rate of $25 \%$ is based on a narrow definition of unemployment that only covers those who are willing to work but cannot find jobs. In addition, South Africa has a great number of people who have given up paying futile effort to find jobs and therefore are excluded from this narrow category of the unemployed. If those chronically jobless people are counted, the unemployment rate (based on the expanded definition) hit $36 \%$ in $2016 .{ }^{5}$ In both definitions, the level of unemployment has not substantially changed in the past two decades. In the next section, the historical origin of social exclusion in South Africa is explained.

\subsection{The Land Question and the History of Inequality}

In Why Nations Fail, Daron Acemoglu and James A. Robinson contrasted inclusive and extractive institutions, citing examples of the US-Mexican border, North and South Korea and other cases in which institutional choices determined the long-term growth paths of nations. Combining normative and empirical discussions, they argued that both political and economic institutions should be inclusive, accountable and open enough to ensure sustainable prosperity. However, a country is not necessarily at liberty to choose a particular set of institutions; an extractive institution might have not been preferred by selfish and short-sighted local politicians, but historically enforced by outside powers. To illustrate this coercive path, they used the historical example of South Africa (Acemoglu and Robinson 2012, Chap. 9), which is worth revisiting here.

The principal cause of persistent inequality in South Africa lies in the history of land dispossession that started in 1652, when the Dutch East Asian Company (VOC: Vereenigde Oost-Indische Compagnie) established the Cape Colony. Joined by the British in the early 19th century, European settlers expanded their territory into today's South Africa depriving indigenous African people of land. The European conquest in this part of Africa was completed in the second half of the 19th century, stimulated by the discovery of diamonds in 1867 and gold in 1886 (Thompson 1990, Chap. 4). The emergence of mining cities like Johannesburg and port cities like Durban boosted demand for food and basic goods. Acemoglu and Robinson (2012, pp. 261-64) noted that this new demand was met by the increased supply of agricul-

\footnotetext{
${ }^{5}$ See "Quarterly Labour Force Surveys." Statistics South Africa Website. http://www.statssa.gov. za/?page_id=1854\&PPN=P0211\&SCH=6813. Accessed October 15, 2017.
} 


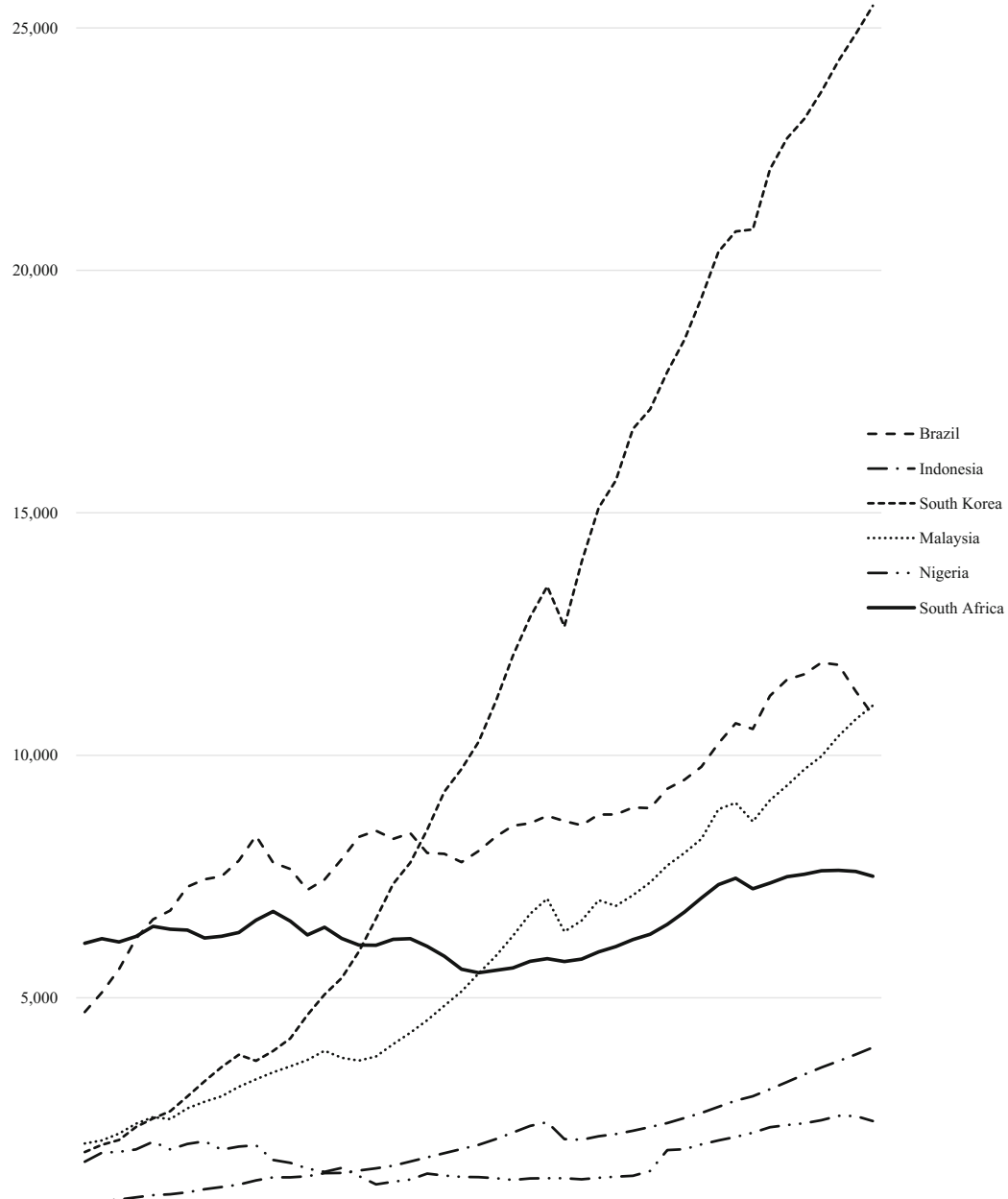

197019721974197619781980198219841986198819901992199419961998200020022004200620082010201220142016

Fig. 9.2 GDP per capita change in South Korea, Malaysia, Indonesia, Brazil, South Africa, and Nigeria, 1971-2010. Source World Bank data. https://data.worldbank.org/indicator/NY.GDP.PCAP. KD. Accessed 15 October 2017 


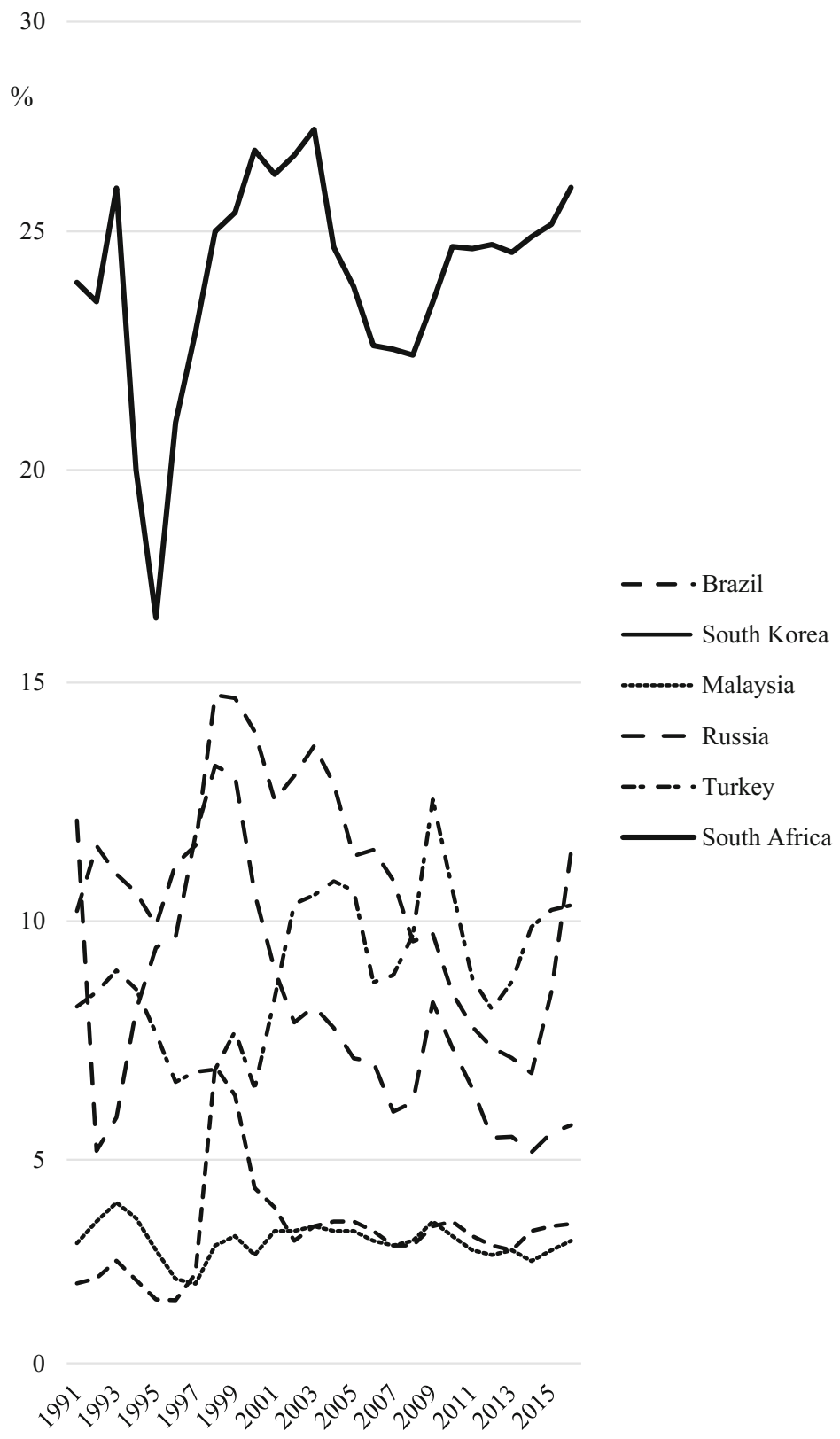

Fig. 9.3 Unemployment in South Africa and other emerging states. Source World Bank data. https://data.worldbank.org/indicator/SL.UEM.TOTL.ZS. Accessed 15 October 2017 
tural products by local African farmers, mainly diligent Christians, rather than white settler farmers. They successfully produced crops such as maize, accumulated capital and even started to purchase farmlands back from white farmers (Bundy 1979).

However, after the South African War (Boer War), the racial dualism of the South African agrarian structure began to consolidate. Under the new regime of the Union of South Africa established in 1910, the authorities prohibited the land ownership of black Africans in areas designated by law as being for whites only, thereby destroying the basis of their autonomous rural livelihoods and enterprises. As vividly described by Sol Plaatje, one of the founders of the ANC, the government evicted black African farmers from white areas often with raw violence (Plaatje 1991). While white farmers began to engage in large-scale subsidized food production in the best parts of the country, black Africans were forced to make their living in so-called native reserves (homelands), which constituted only $13 \%$ of their native soil (Fig. 9.4). Given the necessity for wage income, rural Africans sought job opportunities in the white areas, giving rise to circular migration between the homelands and urban industrial spaces. ${ }^{6}$ The government and industry took it for granted that the homeland economy would supplement the income of migrant households. However, as more black Africans were forcibly relocated from mechanized white farms to the homelands, the latter became over-populated and productivity deteriorated. ${ }^{7}$ Although homeland agriculture accommodated 40-50\% of local food demand in the first half of the 20th century, the rate decreased to $26 \%$ by 1967 (Simkins 1981).

Uprooted from the soil, people flocked to the white areas seeking low-wage jobs, regardless of availability, and this creation of "surplus people" gave origin to today's structural unemployment in South Africa. On the other hand, the urban industry vied for a limited number of skilled and semi-skilled black African workers and called for a relaxation of the draconian regulation of the apartheid labor market. The manufacturing and service sectors were increasingly concerned about the short supply of a skilled workforce as well as the limitations of the consumer market, and called for the appeasement of apartheid (Lipton 1985). This reformist voice from inside the regime contributed to the collapse of apartheid.

We now consider the wider African region to compare experiences. Several African countries other than South Africa also appear extremely unequal in terms of income distribution; examining South Africa's neighbors, GINI coefficients are 0.610 for Namibia and 0.605 for Botswana in 2009. Statistically, however, the extent of inequality tends to be exaggerated in Africa. The income of resource-exporting countries circulates in capital and commercial cities, while a majority of people continue living on a subsistence economy in the countryside where goods and services are produced and consumed without being mediated by money. In this regard, in most African countries, the welfare level of low-income households can be much

\footnotetext{
${ }^{6}$ The economic effect of coercive circular migration was elaborated by a group of neo-Marxist scholars such as Harold Wolpe (1972). See Friedman (2015) for an appraisal.

${ }^{7}$ About 3.5 million black people were forcibly relocated by the authorities from 1960 to 1983 (Platzky and Walker 1985, pp. 10-11, 17). The total South African population was estimated to be around 30 million in 1980.
} 


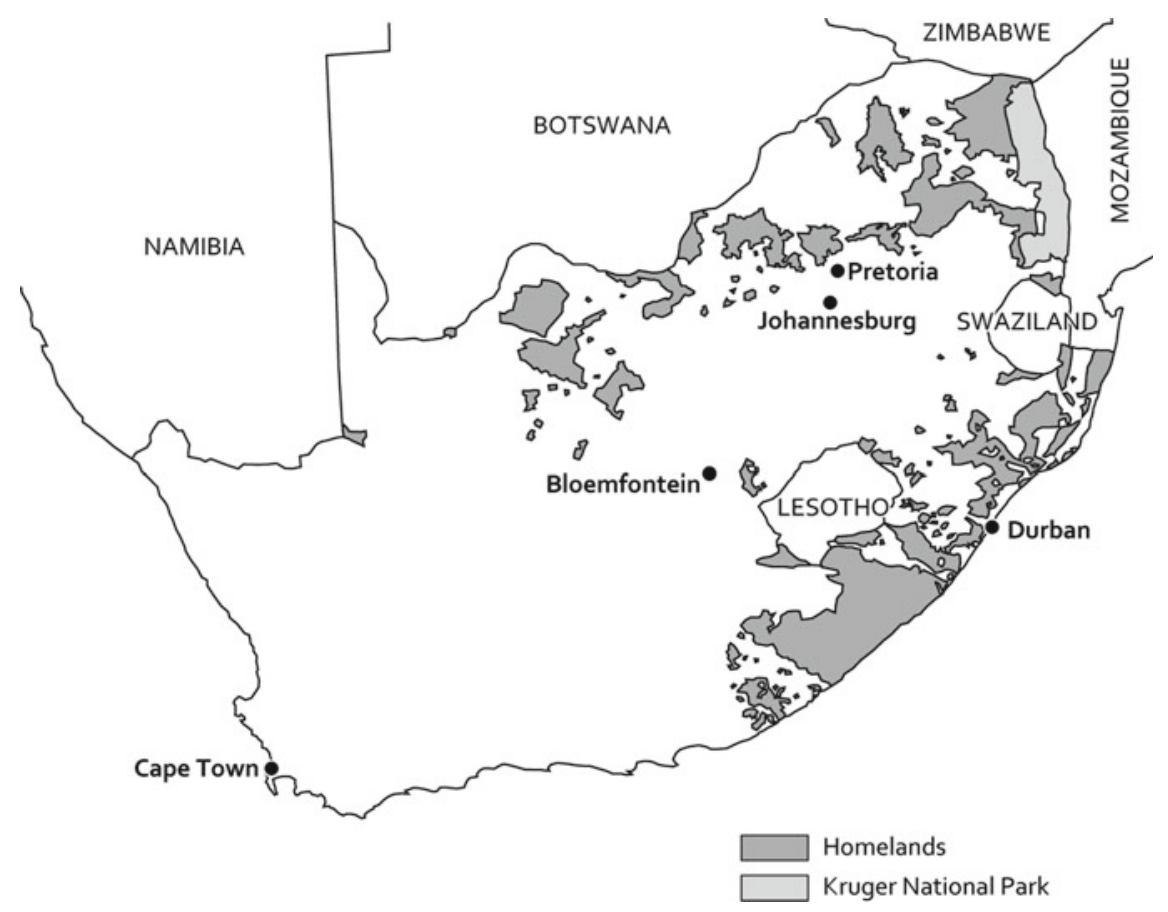

Fig. 9.4 Homelands of South Africa. Source Mine (2013, p. 98)

higher than it appears. In addition, the quality of statistical data on African countries is dubious. In 2010, for example, the Ghana Statistical Services revised the GDP size and increased it by 1.7 times from 22 to 37 billion cedi after improving the calculation method (Jerven 2013, p. 26).

Compared with average African countries, South Africans face inequality in a bare, purer form. As shown in Table 9.1, the ratio of agricultural employment to the total employment is extremely low in South Africa, while the urbanization rate is the highest of all listed countries. The ratio of wage and salaried workers is also very high. In South African villages where informal buffers are lacking, people ride on a minibus to buy maize and other foodstuff at a town supermarket, which becomes particularly crowded after the payment day of social security grants. After the destruction of indigenous agriculture described in this section, the South African countryside polarized into mechanized farmlands on the one hand (former white farming areas), and villages that cease to practice productive farming and instead accommodate a large number of jobless people, on the other (former black homelands). This dichotomy remains intact after the end of apartheid. ${ }^{8}$

\footnotetext{
${ }^{8}$ Only $8-9 \%$ of lands for commercial agriculture was transferred from white ownership to black ownership from 1994 to 2013 (Cousins and Walker 2015, p. 4, 22).
} 
Table 9.1 Rural and informal buffers against inequality

\begin{tabular}{l|l|l|l|l}
\hline & $\begin{array}{l}\text { Employment in } \\
\text { agricultural } \\
\text { sector }(2017, \\
\text { male-female } \%)\end{array}$ & $\begin{array}{l}\text { Urbanization rate } \\
(2016, \%)\end{array}$ & $\begin{array}{l}\text { Wage and } \\
\text { salaried workers } \\
\text { rate (2017, \%) }\end{array}$ & GINI coefficient \\
\hline Angola & n.a. & 44.8 & 46.5 & $0.427(2008)$ \\
\hline Cameroon & $57-67$ & 54.9 & 23.2 & $0.465(2014)$ \\
\hline Congo, DR & $55-76$ & 43.0 & 22.7 & $0.421(2012)$ \\
\hline Cote d'Ivoire & $45-75$ & 54.9 & 23.9 & $0.417(2015)$ \\
\hline Ethiopia & $78-62$ & 19.9 & 51.0 & $0.332(2010)$ \\
\hline Ghana & $46-38$ & 54.7 & 24.7 & $0.422(2012)$ \\
\hline Kenya & $51-75$ & 26.1 & 45.8 & $0.485(2005)$ \\
\hline Nigeria & $38-15$ & 48.6 & 65.9 & $0.430(2009)$ \\
\hline Senegal & $48-57$ & 44.1 & 31.9 & $0.403(2011)$ \\
\hline South Africa & $8-4$ & 65.3 & 85.6 & $0.634(2011)$ \\
\hline South Sudan & n.a. & 19.0 & n.a. & $0.463(2009)$ \\
\hline Tanzania & $64-70$ & 32.3 & 17.7 & $0.378(2011)$ \\
\hline Uganda & $68-76$ & 16.4 & 21.2 & $0.410(2012)$ \\
\hline Zambia & $44-67$ & 41.4 & 22.5 & $0.571(2015)$ \\
\hline Zimbabwe & $64-71$ & 32.3 & 24.9 & $0.432(2011)$ \\
\hline So & & & & \\
\hline
\end{tabular}

Source World Bank data. https://data.worldbank.org/indicator. Accessed 15 October 2017

\subsection{The Rise of the "Black Middle Class"}

Despite the continued distortion of economic structure, South Africa's political landscape has thoroughly transformed after apartheid. Celebrated by all African nations and the international community, the black African majority finally became entitled to vote in 1994. The war machines of the white government and anti-government guerrillas were integrated into a single national defense force, a shining example of post-conflict peace building. The Truth and Reconciliation Commission (TRC) managed to put a lid on the simmering discontent of black Africans over the past racial injustice through its programs such as public hearings, research, amnesty and compensation. In light of polarized group interests in racial capitalism in the last century, it is prodigious that conflicting political forces agreed to govern the country in coalition at least in the short term. What is the nature of this coalition?

First of all, it must be noted that the ANC that triumphed in the first non-racial general elections is a broad coalition itself. The liberation movement formed the Tripartite Alliance with the Congress of South African Trade Unions (COSATU) and the South African Communist Party (SACP) when they entered multi-party negotiations in 1990. Then, a group of progressive, largely neo-Keynesian economists presented a carefully crafted policy recommendation for a post-apartheid government (MERG 
1993), which formed the basis of the Reconstruction and Development Programme (RDP), the ANC's policy platform for the 1994 general elections. However, given the collapse of the Soviet Union, the agenda of a pro-poor mixed economy of the RDP lost momentum, while the cadres of the ANC engaged in behind-the-door negotiations with delegates of the corporate sector on key economic issues in the early 1990s (Terreblanche 2002, pp. 95-109). Even though the agenda of the RDP was shelved, the Tripartite Alliance continued. The organizational machinery of the COSATU and the SACP remains essential for the ANC to canvass for votes in the elections, while the unionists and communists can hold cabinet positions.

Keeping the rhetoric of national liberation, the ANC has fostered, and been supported by, the new "black middle class," which has remarkably expanded under the scheme of Black Economic Empowerment (BEE). Under this scheme, corporate shares and assets were gradually transferred to black African investors, and the principle of employment equity (affirmative action) transformed the landscape of economic decision making; in 2015, 64\% of the top management positions in the national government were occupied by black Africans, though $72 \%$ of the top managers in private firms were still whites (Southall 2016, pp. 73-95; CEE 2016, p. 132, 138). The BEE policy continued under the presidencies of both Thabo Mbeki and Jacob Zuma. In the meantime, organized labor has been allowed to give voice to social and economic policy making through the National Economic Development and Labour Council (NEDLAC), even though the mandate has been short of corporatist joint decision making (Adler 2000). In the COSATU membership, the ratio of white-collar workers rose from $19 \%$ in 1994 to $42 \%$ in 2012, while that of semiskilled and un-skilled workers declined from 60 to $38 \%$ in the same period (Satgar and Southall 2015, p. 28). ${ }^{9}$

Regarding the partnership between the ANC and other parties, the experience of the Government of National Unity (GNU) in which all major political parties formed a coalition government from 1994 to 1999 under the leadership of Mandela is considered a watershed event. Based on the prescription of the interim constitution, the ANC, the NP and the Inkatha Freedom Party (IFP) entered a transitional powersharing arrangement by being allocated cabinet positions according to their shares in the national vote. The NP leader, F.W. de Klerk, served as one of two deputies of President Mandela. The scheme of this grand coalition, modeled on the consociational democracy propounded by Lijphart (1985), dramatically contributed to the reconciliation of racial groups (Mine 2013). Lijphart's original proposition consisted of four elements: grand coalition, proportional representation, federal government and mutual veto. After multi-party negotiations, all political players agreed to this set of government design except for mutual veto, which was dropped to avoid gridlock and to advance affirmative action.

The national elections became competitive rather than consensual after the dissolution of the GNU in 1999. However, South Africa's post-apartheid elections are

\footnotetext{
${ }^{9}$ Dani Rodrik argued that in South Africa, the shrinkage of export-oriented manufacturing was the main factor in the failure of job creation, especially for the relatively unskilled workforce, in contrast to the case of Malaysia (Rodrik 2008).
} 
Table 9.2 Results of general elections (PR system) (\%)

\begin{tabular}{l|l|l|l|l|l}
\hline & 1994 & 1999 & 2004 & 2009 & 2014 \\
\hline $\begin{array}{l}\text { African National Congress } \\
(\text { ANC) }\end{array}$ & 62.65 & 66.35 & 69.69 & 65.90 & 62.15 \\
\hline Congress of the People (COPE) & - & - & - & 7.42 & 0.67 \\
\hline $\begin{array}{l}\text { Economic Freedom Fighters } \\
(\text { EFF })\end{array}$ & - & - & - & - & 6.35 \\
\hline $\begin{array}{l}\text { National Party (NP)/ } \\
\text { New National Party (NNP) }\end{array}$ & 20.39 & 6.87 & 1.65 & - & - \\
\hline $\begin{array}{l}\text { Democratic Party } \\
(\text { DP)/Democratic Alliance (DA) }\end{array}$ & 1.73 & 9.56 & 12.37 & 16.66 & 22.23 \\
\hline $\begin{array}{l}\text { Inkatha Freedom Party } \\
\text { (IFP) }\end{array}$ & 10.54 & 8.58 & 6.97 & 4.55 & 2.40 \\
\hline $\begin{array}{l}\text { President-elect of the ANC and } \\
\text { the Republic of South Africa }\end{array}$ & Mandela & Mbeki & Mbeki & Zuma & Zuma \\
\hline
\end{tabular}

Source Electoral Commission of South Africa. http://www.elections.org.za/content/Elections/ National-and-provincial-elections-results/. Accessed 15 October 2017

still considered a sort of "race censuses." According to the Census 2011, African people accounted for $79 \%$ of the total population, while the shares of whites and Coloureds were $9 \%$ each. A rule-of-thumb interpretation that whites and Coloureds vote the right-leaning "white parties" (NP/NNP and DP/DA), while black Africans vote the left-leaning "black parties" (ANC, COPE, EFF and IFP) may seem close to the reality (Table 9.2). A small but critical trend is that the gravity of Coloured votes has gradually shifted from the ANC to the Democratic Alliance (DA).

Nevertheless, the relations between major political parties cannot be explained only in terms of race factors. To the "left" of the ANC, the Economic Freedom Fighters (EFF) is consolidating its presence. ${ }^{10}$ The EFF is led by Julius Malema, the former leader of the ANC Youth League who was expelled from the ANC for disciplinary reasons in 2012. Resorting to radical discourse such as land redistribution without compensation, the EFF has sought support from the young African underclass and unemployed, and is often regarded as a dangerous "populist" party. Since 2015, education at South African universities has been disrupted by the popular student campaign "\#Fees-Must-Fall” against the proposed increase in tuition fees (Booysen 2017). Having engaged in the movement, the EFF is also giving voice to the educated and frustrated black African youth.

To the "right" of the ANC is the DA, which originated as a liberal anti-apartheid party supported by English-speaking whites and joined by Afrikaans-speaking constituencies after the demise of the NP/NNP. The DA largely remains a party of whites and Coloureds, and is dominant in the Western Cape, the wealthiest province. However, if a South African political party wants to break through its minority position

\footnotetext{
${ }^{10}$ Another ANC offshoot, the Congress of the People (COPE), was formed mainly by supporters of former president Thabo Mbeki, but has become almost negligible by the 2014 elections.
} 
in national politics, it is essential to garner the votes of black Africans. In 2015, the DA elected a black moderate politician, Mmusi Maimane, as the party leader. It is evident that as the legacy of struggle wanes, all major opposition parties aim at ripping the votes of the "black middle class" from the colossus ANC, which has been supported by a medley of community activists, trade unionists, financial magnates and rural traditional leaders. The BEE policy seems to be mostly endorsed by all political parties based on dual expectations; the "black middle class" is regarded as a vanguard of the advancement of the black majority and can also be a buffer to preserve a deracialized capitalist order. ${ }^{11}$

Based on the 2008 data, Jeremy Seekings and Nicoli Nattrass classified South African households into "lower" (37\% of households and $10 \%$ of income), "middle" (46\% of households and 35\% of income) and "upper" categories (17\% of households and 55\% of income). The chronically unemployed and farm and domestic workers form the core of the "lower" classes. The size of the "middle," i.e., bluecollar and white-collar workers as well as nurses and teachers, has somewhat shrunk in the context of deindustrialization, while the "upper" classes such as managers and professionals are growing and becoming increasingly multi-racial (Seekings and Nattrass 2005, Chap. 9; 2016, p. 120). Two decades after liberation, social mobility has slowed down, and the spill-over effect of skills and knowledge across strata remains limited. As an alternative measurement of inequality, the Palma ratio attracts attention of economists (Palma 2011). This is the ratio of the richest 10\% of the population's share of gross national income (GNI) divided by the poorest 40 percent's share. Given that the income share of the in-between $50 \%$ of the population is almost constant (about half of GNI) across countries and over time, this ratio highlights the state of income inequality in a more straightforward way than GINI. The ratio is 7.1 in South Africa, 3.5 in Brazil, 2.6 in Malaysia, 2.2 in Nigeria, 2.0 in the United States, 1.8 in Indonesia, and 1.2 in Japan. The figure for South Africa is the highest in the world (the latest available data during the period of 2010-2015) (UNDP 2016, pp. 206-9).

In order to expand the growth capacity of South Africa, it is required to improve productivity and innovativeness of the workforce by investing in research and human capital formation and by socially stabilizing the "black middle class."12 South Africa's investment in R\&D is not impressively high: in 2013, the ratio of $R \& D$ spending to GDP was $0.7 \%$ in South Africa, between Turkey's $0.8 \%$ and Mexico's $0.5 \%$, and much lower than China's $2 \%$ and South Korea's $4 \% .{ }^{13}$ As the BEE policy creates strong demand for young black Africans with higher degrees, the share of black students enrolled in tertiary education institutions rose from 38 to $71 \%$ between 1990 and 2015, while the share of white students decreased from 50 to $16 \%$ in the

\footnotetext{
${ }^{11}$ Throughout the 20th century, it was a consistent policy objective for the white government to separate between urban workers settled in cities and migrant workers rooted in the countryside (Hindson 1987). The former is the historical origin of today's "black middle class."

${ }^{12}$ Southall (2016, p. 62) categorizes middle managers and independent professionals as "upper middle class" rather than the "upper" defined by Seekings and Nattrass.

${ }^{13} \mathrm{OECD}$ database: https://data.oecd.org/rd/gross-domestic-spending-on-r-d.htm. Accessed October 15, 2017.
} 
same period (SAIRR 1995, pp. 259-61; Council on Higher Education 2017, p. 3). ${ }^{14}$ However, despite efforts of expanding the educational basis, skilled black African professionals are still in short supply. Some black African university graduates do not want to be stigmatized by affirmative action, in that they may be considered less competent than their white colleagues.

Given the growing number of educated urban black Africans and their frustration, all major political parties have begun vying for their votes. As argued by Southall (2016), one of the major characteristics of the South African "black middle class" is their dependency on the party-state structure. Recognizing that state patronage has greatly contributed to the ANC rule, the opposition parties strategically expanded their sphere of influence in major metropolitan areas through local elections, bidding for greater access to state power. At the societal level, the propensity toward statism is reflected in the low level of entrepreneurship in South Africa: the ratio of those engaged in early-stage entrepreneurial activities to the working-age population was only $8 \%$ on average from 2014 to 2016 , compared to $13 \%$ in China, $18 \%$ in Thailand, $19 \%$ in Brazil, 26\% in Chile, $28 \%$ in Burkina Faso and $30 \%$ in Cameroon (Global Entrepreneurship Research Association 2017; OECD 2017).

\subsection{Reform Deferred}

In order to forge an effective coalition for technology upgrade and equitable redistribution, there should not be too many or too few effective veto players. Given diverse interests, if there are too many veto players, no policy may be agreed on, and if too few, an agreed policy may not be implemented thoroughly. The former leads to the lack of decisiveness, increasing the risk of "stalemate or gridlock", while the latter leads to the lack of resoluteness, increasing the risk of "rapid or frequent policy change" (Doner 2009; Cox and McCubbins 2001, p. 27). The latter seems to apply in South Africa, where a set of articulated policies is adopted at the party-state level, not thoroughly implemented, eventually replaced by an ostensibly new policy framework, and the cycle repeats. Although South African political parties exchange scathing attacks in parliament and the mass media in veto-type language, the strife between them revolves around politicians" "behaviors" and "attitudes" such as corruption and racist remarks, rather than around the appropriateness of policies. Although the EFF calls for the nationalization of mines and appropriation of white farms, the agenda largely remains rhetorical and is rarely discussed as concrete policy programs at least for the moment.

A good example of the lack of resoluteness can be found in development policy making. Thabo Mbeki, the successor of Mandela, sidelined the social democratic RDP and unveiled a new policy framework called the Growth, Employment and Redistribution (GEAR) in 1996. The GEAR gave weight to economic growth as a precondition of job creation and redistribution, and prioritized fiscal discipline,

\footnotetext{
${ }^{14}$ The figure of 1990 covers the enrolment in universities, technikons and teacher training colleges.
} 
wage restraints, tax reduction, trade liberalization and the promotion of foreign direct investment (FDI) (Government of South Africa 1996). Although they were part of the ruling coalition, the COSATU and the SACP were skeptical of the GEAR, criticized "neo-liberal" Mbeki and helped Jacob Zuma to take the helm of the ANC in 2007 and to rise to the state president in 2009. Having gone through the left-leaning RDP and the right-leaning GEAR, the government of Zuma released the National Development Plan (NDP) in 2013 to table a middle-ground agenda. Resonating with Amartya Sen (1999), the NDP explicitly set the expansion of people's capabilities as the ultimate goal of development, highlighted infrastructure development and aimed at job creation by making the labor market more flexible. Although the NDP called for the leadership "to convince South Africans of the need to make mutual sacrifices for longer-term benefits" (NPC 2011, p. 10), the essential part of the NDP has not been translated into concrete action since its release.

The major problem of contemporary South African politics is that few political vehicles have committed to giving voice to poor South Africans who are, as a social group, "dispersed between countless local associations, community organisations and NGOs" (Bundy 2014, p. 156). As discussed in previous sections, more than one third of the working-age population have no access to jobs, and the origin of this massive joblessness lies in the history of land dispossession. The underclass people who get by each day on the periphery of urban townships or in the countryside have ceased to pin their hopes on formal party politics. The ratio of those who casted their ballots in general elections to the eligible voters has decline from $86 \%$ in 1994 to $57 \%$ in 2014 , meaning that only $35 \%$ of all potential voters voted the ruling ANC in the latter year. Those who voted other parties are fewer.

The grievances of the bottom layer of the population have been eased to some extent by thin and widespread social security benefits financed largely by the rent of natural resources. Capitalizing on the old system of welfare handouts developed in the apartheid era, the post-apartheid government expanded social security cash grants for the vulnerable population, especially the elderly, the handicapped, and the families with dependent children (Marais 2010, pp. 238-261; Seekings and Nattrass 2016, pp. 139-167). In 2017, the old-age grant and the disability grant were R1,600 (approximately US\$120) per person per month, while the child support grant was R380 per child. The number of cash grant recipients amounted to 17.2 million, nearly one third of the total population, in February 2017. This corresponds to the "lower" category of the South African population. ${ }^{15}$

As the absolute size of South African population increases, it will become imperative for the government to enlarge the budget revenue in order to expend more social security grants. While the NDP did not discuss much on taxation, the Organisation for Economic Co-operation and Development (OECD) specifically recommended that South Africa should broaden the income tax base and increase the tax rate for the wealthy population, which would not only improve fiscal sustainability but also

\footnotetext{
${ }^{15}$ The population of South Africa was 55.9 million in 2016. The number of recipients is released every month at the website of the South African Social Security Agency (Sassa). http://www.sassa. gov.za/index.php/homepage. Accessed October 15, 2017.
} 
reduce inequality (OECD 2015). The ratio of tax revenue to GDP in South Africa in $2013(27 \%)$ was not very high compared to other middle-income countries like Brazil and Argentina (around 35\% for both) (Luiz 2016a, p. 213). However, the government has hardly discussed tax reforms that might deliver a blow to the multi-racial wealthy classes. Making public sector services more efficient is another crucial task. In this connection, at the end of Mbeki's presidency, keen attention was paid to the notion of a Democratic Developmental State (Edigheji 2010) in part as a response to violent protest against the delay of service delivery in the townships. Although this agenda of state capacity and efficiency was taken up in the NDP, the extent of reforms has not been closely monitored.

The historical impact of development and welfare policies is shown in Fig. 9.5 However counterintuitive it may be, the wealthiest classes became less rich during the apartheid period. This is primarily because of the affirmative action targeting Afrikaners vis-à-vis English-speaking whites. Looking at the post-apartheid trend, the number of people living below the poverty line has decreased since the beginning of the 2000s due to the expansion of social security grants. ${ }^{16}$ Although this cash transfer is supposed to be instrumental in alleviating not only absolute poverty but also relative inequality, the household surveys show that post-apartheid society is more unequal than apartheid society was; the GINI coefficient rose in the early 2000s on top of already high inequality for the previous three decades. This can primarily be attributed to the steep upturn of the income of the most affluent population. Although both radical deregulation of the labor market and income tax reforms to capture various forms of rent more efficiently are indispensable for job creation and inclusive development in a country like South Africa, political parties have failed to represent the critical part of the population that would benefit most from radical "painful" reforms. ${ }^{17}$ As the development economist Arthur Lewis remarked in postindependence Ghana, "In Europe, socialist parties were built by a coalition of trade unions and middle-class intellectuals. In Africa both these groups are on the wrong side. The underdog is the farmer, and both the trade unions and the educated classes live by sucking the farmer's blood" (Lewis 1969, p. 69). South Africa may not be an exception to this pattern; what is worse, the difference is that the South African underclass people are landless.

On August 16, 2012, more than thirty workers were shot to death by the security police as a consequence of violent confrontations at the Marikana platinum mine. Before the incident, groups of unskilled workers had broken away from a COSATUaffiliated trade union, formed their own, attempted to go on strike for higher wages and attacked the security police. The execution-style retaliation killings by policemen horrified the entire nation and goaded young activists to part with the ANC and organize the EFF. The political strategy of the SACP and the COSATU is called

\footnotetext{
${ }^{16}$ Statistics South Africa (2017) reports a slight increase in poverty headcount from 2011 to 2015 due to sluggish economy.

${ }^{17}$ John M. Luiz refers to the current South African political dispensation as "bounded populism," which "sacrifices innovation with an elaborate rent-granting system while retaining economic stability, be it at a low level" (Luiz 2016b, pp. 16-17).
} 


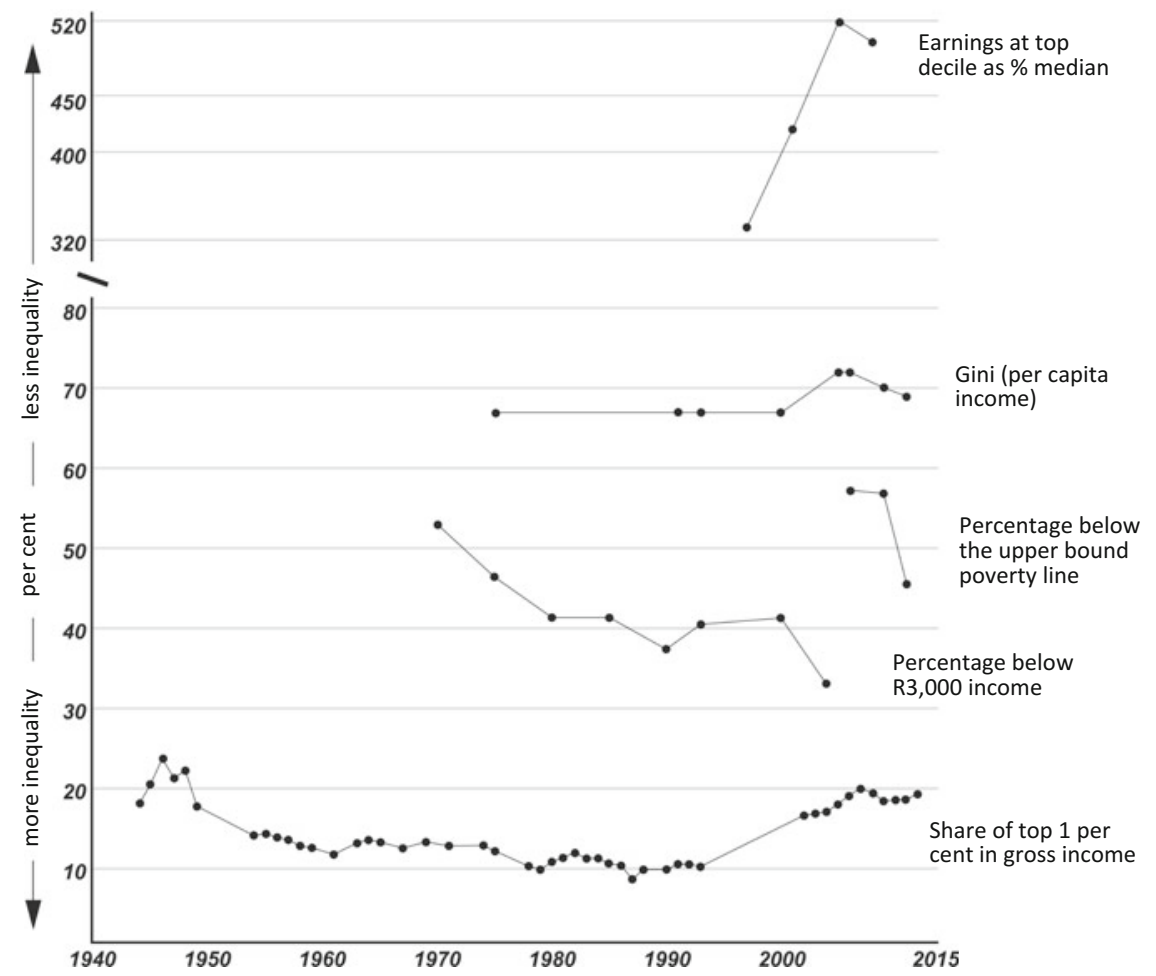

Fig. 9.5 Economic inequality in South Africa. Source Atkinson et al. (2017). As for the definitions of poverty lines, see Statistics South Africa (2017, pp. 114-17)

national democratic revolution (NDR): associating with patriotic bourgeoisie in the first stage and preparing for a socialist revolution in the second stage. However, their strategic alliance with business elites can be easily regarded as a betrayal of the cause of the working class. On the other hand, it is problematic to regard formal sector workers as a "labor aristocracy," not least because "massive unemployment and poverty among the majority of the black population requires employed workers to share their wage with a large number of dependents - immediately dissolving their 'privilege""' (Satgar and Southall 2015, p. 27).

The basic demographic fact is that the generation with no memory of the antiapartheid struggle is becoming a majority force of society. For them, selfless ANC activists like Mandela exist only in school textbooks. It is impossible to demand the loyalty of this generation to the ruling party through skimpy side payments. However, unless they are politically organized, the deprived cannot exercise veto to state policies that count seriously against them. As the precondition for an effective interest coordination to take place, all major group interests should be appropriately represented in the political space. 


\subsection{Conclusion: Addressing Both Pressing Issues and Root Causes}

Anthony Atkins noted that the goal is not to achieve total equality but "to reduce inequality below its current level, in the belief that the present level of inequality is excessive" (Atkinson 2015, 9). Excessive inequality is not only morally intolerable but also socio-economically unsustainable (Stiglitz 2013). Doner and Schneider (2016) referred to three major deterrents that would impede effective upgrading coalitions in middle-income countries: inequality, informality and nationalist reactions to FDI. The question of informality is irrelevant in South Africa, where the indigenous rural informal economy was wiped out in the first place by the apartheid regime. Foreign control is not a central issue either; South African-born enterprises such as Anglo American, Old Mutual, BHP Billiton and SABMiller are all global players listed in London, and the problem is rather that the operations of these large enterprises do not have significant domestic spill-over effects. Therefore, only one factor remains. The case of this chapter is that excessive inequality is the most significant factor hampering sustainable growth in South Africa.

Given that South Africa exhibits characteristics of both middle-income and lowincome countries, it is essential to clearly distinguish short-term and long-term challenges and address them simultaneously. In the short term, for a middle-income country like South Africa to catch up, technological capacity must be upgraded by investing substantially in R\&D and human capital. For all the constraints discussed in this chapter, the chief advantage of the abolishment of apartheid for the South African economy is that inexhaustible human resources became available without racial segregation and labor-market dirigisme. The current "trap" of South Africa can be attributable not least to the structural weakness of human capital formation and weak spill-over effects of skills and innovation capacity to lower ranks of the workforce. The government should therefore continue giving support to higher education, vocational training, and the promotion of entrepreneurship (OECD 2017). Many South African universities, which boast a long history of resisting the irrationality of apartheid, still maintain top-class research capacity in Africa. Education provides the major route of upward mobility of the historically disadvantaged majority, and the present policy direction in which the advancement of black African professionals is pursued is not wrong in itself, though the private sector may play a greater role in achieving this objective.

In the longer term, the legacy of colonialism and racism can be dissolved only with time and care. Given that the ultimate cause of the extremity of today's inequality in South Africa lies in centuries of land dispossession, the most straightforward solution will be to bring the land back to the landless people. However, people who were uprooted from the soil decades and centuries ago do not remember how to make a living in agriculture. The politics of land is so complicated that there is no other way than to patiently repeat experiments taking into account diverse factors such as the environment, gender, class, customary laws, job creation and productivity (Cousins and Walker 2015). It is also worth revisiting the idea of the manufacturing-agricultural 
complex based on forward and backward linkage effects of the agricultural sector (MERG 1993, pp. 171-175). Widespread inertia in post-apartheid land reform is due to the paucity of pressure groups representing the interests of the rural poor. As emphasized throughout this chapter, the prospect for inclusive politics will determine the long-term path of development and democracy in South Africa. The responsibility to go beyond the politics of handout distribution rests on all political parties, and under the decentralized political dispensation in the post-apartheid era, the local government will be the major terrain of power struggle and democratic transformation (Hart 2002). With a background of trade unionist-turned-financial magnate, President Cyril Ramaphosa, the successor of Zuma, faces a rocky road ahead.

Finally, is South Africa an exceptional case in Africa? Looking back at agrarian history, the process of thorough land dispossession and the emergence of capitalist, mechanized agriculture in 20th century South Africa is a clear exception in subSaharan Africa (Bernstein 1996). However, looking at the future, the development patterns of African countries characterized by rapid urbanization and even land grabbing may converge on the South African pattern (Iliffe 1987; Mine 2017). In this respect, for other emerging nations in Africa, learning from the policy experience of South Africa will be more realistic than emulating East Asian miracles. On the other hand, economic cooperation in a larger African region will provide great opportunities for South Africa itself as well as for the rest of the continent. The ratio of intra-regional trade to all exports in the Southern African Development Community (SADC) is only 10\%, much lower than $25 \%$ in the Association of Southeast Asian Nations (ASEAN) and 40\% in the European Union (EU) (OECD 2017, p. 70). There is much room for coordination of national interests at the SADC level to promote intra-trade and upgrade regional value chains.

\section{References}

Acemoglu, Daron, and James A. Robinson. 2012. Why Nations Fail: The Origins of Power, Prosperity, and Poverty. New York: Crown Publishers.

Adler, Glenn (ed.). 2000. Engaging the State and Business: The Labour Movement and Codetermination in Contemporary South Africa. Johannesburg: Witwatersrand University Press.

ANC (African National Congress). 1994. The Reconstruction and Development Programme. http:// www.anc.org.za/documents/Policy-Documents/any-author/any-year. Accessed 15 Oct 2017.

Atkinson, Anthony B. 2015. Inequality: What Can Be Done?. Cambridge, MA: Harvard University Press.

Atkinson, Anthony B., Joe Hasell, Salvatore Morelli, and Max Roser. 2017. The Chartbook of Economic Inequality. https://www.chartbookofeconomicinequality.com/inequality-by-country/ south-africa/. Accessed 15 Oct 2017.

Barnes, Justin. 2014. Unpacking South Africa's Position within the Automotive Global Value Chain. ERLN Issues Series 1. http://www.erln.org.za/images/jevents/54574adc3ec802.21284015.pdf. Accessed 15 Oct 2017.

Bernstein, Henry, ed. 1996. South Africa's Agrarian Question: Extreme and Exceptional? In The Agrarian Question in South Africa, ed. Henry Bernstein, 1-52. London: Frank Cass.

Booysen, Susan, ed. 2017. Fees Must Fall: Student Revolt, Decolonisation and Governance in South Africa. Johannesburg: Witwatersrand University Press. 
Bundy, Colin. 1979. The Rise and Fall of the South African Peasantry. Berkeley and Los Angeles: University of California Press.

Bundy, Colin. 2014. Short-Changed? South Africa since Apartheid. Athens, OH: Ohio University Press.

CEE (Commission for Employment Equity). 2016. The 16th Commission for Employment Equity Annual Report 2015-2016. Pretoria: Department of Labour.

Council on Higher Education, VitalStats: Public Higher Education 2015. Pretoria: Council on Higher Education. http://www.che.ac.za/sites/default/files/publications/VitalStats_2015.pdf. Accessed 15 Oct 2017.

Cousins, Ben, and Cherryl Walker. 2015. Land Divided, Land Restored: Introduction. In Land Divided, Land Restored: Land Reform in South Africa for the 21st Century, ed. Ben Cousins and Cherryl Walker, 1-23. Johannesburg: Jacana.

Cox, Gary W., and Mathew D. McCubbins. 2001. The Institutional Determinants of Economic Policy Outcomes. In Presidents, Parliaments, and Policy, ed. Stephan Haggard and Mathew D. McCubbins, 21-63. Cambridge: Cambridge University Press.

Doner, Richard F. 2009. The Politics of Uneven Development: Thailand's Economic Growth in Comparative Perspective. Cambridge: Cambridge University Press.

Doner, Richard F., and Ben Ross Schneider. 2016. The Middle-income Trap: More Politics than Economics. World Politics 68 (4): 608-644.

Edigheji, Omano (ed.). 2010. Constructing a Democratic Developmental State in South Africa. Pretoria: HSRC Press.

Feinstein, Charles H. 2005. An Economic History of South Africa: Conquest, Discrimination and Development. Cambridge: Cambridge University Press.

Friedman, Steven. 2015. Race, Class and Power: Harold Wolpe and the Radical Critique of Apartheid. Pietermaritzburg: University of KwaZulu-Natal Press.

Global Entrepreneurship Research Association. 2017. Global Entrepreneurship Monitor 2016/17 Global Report. http://www.gemconsortium.org/report. Accessed 15 Oct 2017.

Government of South Africa. 1996. Growth, Employment and Redistribution: A Macroeconomic Strategy. Pretoria: Department of Finance. http://www.gov.za/documents/growth-employmentand-redistribution-macroeconomic-strategy-south-africa-gear. Accessed 15 Oct 2017.

Hart, Gillian. 2002. Disabling Globalization: Places of Power in Post-Apartheid South Africa. Berkeley and Los Angeles: University of California Press.

Hindson, Dough. 1987. Pass Controls and the Urban African Proletariat in South Africa. Johannesburg: Ravan Press.

Iliffe, John. 1987. The African Poor: A History. Cambridge: Cambridge University Press.

Jerven, Morten. 2013. Poor Numbers: How We Are Misled by African Development Statistics and What to Do about It. Ithaca: Cornell University Press.

Kharas, Homi, and Harinder Kohli. 2011. What Is the Middle income Trap, Why Do Countries Fall into It, and How Can It Be Avoided? Global Journal of Emerging Market Economies 3 (3): 281-289.

Lewis, W.Arthur. 1969. Some Aspects of Economic Development. London: George Allen and Unwin.

Lijphart, Arend. 1985. Power-Sharing in South Africa. Berkeley: Institute of International Studies, University of California.

Lipton, Merle. 1985. Capitalism and Apartheid: South Africa, 1910-1986. Aldershot: Wildwood House.

Luiz, John. 2016a. The Missing Social Contract for Economic Development in South Africa. In State of the Nation, South Africa 2016: Who is in Charge?, ed. Daniel Plaatjies et al., 205-219. Pretoria: HSRC Press.

Luiz, John. 2016b. The Political Economy of Middle-income Traps: Is South Africa in a Long-Run Growth Trap? The Path to 'Bounded Populism'. South African Journal of Economics 84(1): 3-19.

Marais, Hein. 2010. South Africa Pushed to the Limit: The Political Economy of Change. Cape Town: UCT Press. 
MERG (Macroeconomic Research Group). 1993. Making Democracy Work: A Framework for Macroeconomic Policy in South Africa. Bellville, Western Cape: Center for Development Studies.

Milanovic, Branko. 2011. The Haves and the Have-Nots: A Brief and Idiosyncratic History of Global Inequality. New York: Basic Books.

Mine, Yoichi. 2017. Dreaming Afrasia. In Routledge Handbook of Africa-Asia Relations. London: Routledge.

Mine, Yoichi. 2013. Beyond Ad hoc Power-Sharing: Comparing South Africa and Zimbabwe. In Preventing Violent Conflict in Africa: Institutions, Inequalities and Perception, eds. Yoichi Mine, Frances Stewart, Sakiko Fukuda-Parr and Thandika Mkandawire, 95-125. Basingstoke: Palgrave Macmillan.

NPC (National Planning Commission). 2011. National Development Plan: Vision for 2013. Pretoria: NPC. http://www.gov.za/sites/www.gov.za/files/devplan_2.pdf. Accessed 15 Oct 2017.

OECD (Organisation for Economic Co-operation and Development). 2015. OECD Economic Surveys South Africa 2015. Paris: OECD.

OECD. 2017. OECD Economic Surveys South Africa 2017. Paris: OECD.

Palma, Gabriel José. 2011. Homogeneous Middles vs. Heterogeneous Tails, and the End of the 'Inverted-U': It's All About the Share of the Rich. Development and Change 42 (1): 87-153.

Plaatje, Sol T. 1991. Native Life in South Africa: Before and since the European War and the Boer Rebellion. Athens, OH: Ohio University Press.

Platzky, Laurine, and Cherryl Walker. 1985. The Surplus People: Forced Removals in South Africa. Johannesburg: Ravan Press.

Rodrik, Dani. 2008. Understanding South Africa's Economic Puzzles. Economics of Transition 16 (4): 769-797.

SAIRR (South African Institute of Race Relations). 1995. Race Relations Survey 1994/95. Johannesburg: SAIRR.

Seekings, Jeremy, and Nicoli Nattrass. 2005. Class, Race, and Inequality in South Africa. New Haven and London: Yale University Press.

Seekings, Jeremy, and Nicoli Nattrass. 2016. Poverty, Politics and Policy in South Africa: Why Has Poverty Persisted after Apartheid? Johannesburg: Jacana.

Sen, Amartya. 1999. Development as Freedom. New York: Alfred A. Knopf.

Simkins, Charles. 1981. Agricultural Production in the African Reserves of South Africa, 1918-1969. Journal of Southern African Studies 7 (2): 256-283.

Satgar, Vishwas, and Roger Southall. 2015. COSATU in Crisis: Analysis and Prospect. In COSATU in Crisis: The Fragmentation of an African Trade Union Federation, ed. Vishwas Satgar and Roger Southall, 1-34. Sandton: KMM Review.

Southall, Roger. 2016. The New Black Middle Class in South Africa. Johannesburg: Jacana.

Statistics South Africa. 2017. Poverty Trends in South Africa: An Examination of Absolute Poverty between 2006 and 2015. http://www.statssa.gov.za/publications/Report-03-10-06/Report-03-10062015.pdf. Accessed 15 Oct 2017.

Stiglitz, Joseph E. 2013. The Price of Inequality. New York: W. W. Norton.

Terreblanche, Sampie. 2002. A History of Inequality in South Africa, 1652-2002. Pietermaritzburg: University of Natal Press.

Thompson, Leonard. 1990. A History of South Africa. New Haven and London: Yale University Press.

UNDP (United Nations Development Programme). 2016. Human Development Report 2016: Human Development for Everyone. New York: UNDP. http://hdr.undp.org/sites/default/files/ 2016_human_development_report.pdf. Accessed 15 Oct 2017.

Wolpe, Harold. 1972. Capitalism and Cheap Labor Power in South Africa: From Segregation to Apartheid. Economy and Society 1 (4): 425-456. 
Open Access This chapter is licensed under the terms of the Creative Commons AttributionNonCommercial-NoDerivatives 4.0 International License (http://creativecommons.org/licenses/bync-nd/4.0/), which permits any noncommercial use, sharing, distribution and reproduction in any medium or format, as long as you give appropriate credit to the original author(s) and the source, provide a link to the Creative Commons license and indicate if you modified the licensed material. You do not have permission under this license to share adapted material derived from this chapter or parts of it.

The images or other third party material in this chapter are included in the chapter's Creative Commons license, unless indicated otherwise in a credit line to the material. If material is not included in the chapter's Creative Commons license and your intended use is not permitted by statutory regulation or exceeds the permitted use, you will need to obtain permission directly from the copyright holder.

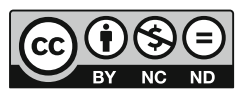

